\title{
DETEKSI WAJAH BERBASIS FACIAL LANDMARK MENGGUNAKAN OPENCV DAN DLIB
}

\author{
RR Hajar Puji Sejati ${ }^{1}$, Rodhiyah Mardhiyyah ${ }^{2}$ \\ Program Studi Informatika Medis ${ }^{1}$, Program Studi Teknik Komputer ${ }^{2}$, Universitas Teknologi Yogyakarta \\ Jl. Siliwangi Ring Road Utara Jombor Lor Sleman Yogyakarta \\ hajarsejatiestaff.uty.ac.id, rodhiyahestaff.uty.ac.id
}

\begin{abstract}
Computer science and information technology have advanced in a variety of sectors that were previously unachievable due to constraints such as hardware. Computer vision can be used to recognize an object using computer science. Objects can be recognized by taking or recording photos or videos and then processing them using specific tools and methodologies. The goal of the facial landmark-based face detection research using OpenCV and Dlib is to perform face detection in people so that it can be used for a variety of purposes in the future. The strategy employed in this study was the usage of facial landmarks using OpenCV and Dlib to improve face detection accuracy. Face detection has been effectively carried out based on facial landmark points, according to the findings of testing the entire system. Face landmark-based face detection is more accurate using the OpenCV Dlib, which can be seen during processing in the OpenCV Dlib, which can precision photos based on facial movements.
\end{abstract}

Keywords - Computer Vision, Face Detection, Facial Landmark, OpenCV, Dlib

\begin{abstract}
Abstrak - Ilmu komputer dan teknologi informasi telah membuat perkembangan lebih lanjut di berbagai bidang yang sebelumnya tidak tercapai karena adanya keterbatasan seperti keterbatasan perangkat keras. Ilmu komputer melalui computer vision dapat digunakan untuk mengenali sebuah objek. Objek dapat dideteksi melalui gambar atau video yang diambil atau direkam kemudian diproses menggunakan tools dan metode tertentu. Tujuan yang akan dicapai dalam penelitian deteksi wajah berbasis facial landmark menggunakan openCV dan Dlib adalah untuk melakukan deteksi wajah pada manusia sehingga kedepannnya dapat dimanfaatkan untuk berbagai kebutuhan yang memanfaatkan deteksi wajah. Metode yang digunakan dalam penelitian ini adalah penerapan facial landmark menggunakan OpenCV dan Dlib untuk mendapatkan akurasi dalam deteksi wajah yang lebih baik. Dari hasil pengujian keseluruhan sistem, deteksi wajah telah berhasil dilakukan sesuai dengan titik facial landmark. Dengan adanya Dlib OpenCV menjadikan deteksi wajah berbasis facial landmark lebih akurat yang dapat ditunjukkan saat pemrosesan pada Dlib OpenCV yang dapat mempresisikan gambar menyesuaikan pergerakan wajah.
\end{abstract}

Kata Kunci - Computer Vision, Deteksi Wajah, Facial Landmark, OpenCV, Dlib

\section{PENDAHULUAN}

Komputer merupakan perangkat elektronik yang menerima data sesuai dengan instruksi yang diberikan sebelumnya, melakukan perhitungan, dan membuat keputusan logis untuk menghasilkan data yang berarti. Sejak pertama kali diperkenalkan ke publik, komputer telah mengalami kemajuan dalam perangkat keras dan metode baru. Dengan perkembangan komputer, ilmu komputer dan teknologi informasi telah membuat perkembangan lebih lanjut di berbagai bidang yang sebelumnya tidak mungkin dicapai karena keterbatasan perangkat keras seperti computer vision.

Computer vision merupakan penggunaan komputer untuk mengidentifikasi dan mengklasifikasikan isyarat visual untuk memperoleh informasi dari gambar dan video. Computer vision menggabungkan kamera, komputasi penyimpanan berbasis server, perangkat lunak, dan kecerdasan buatan (AI) sehingga sistem dapat melihat dan mengenali objek. Sistem visi komputer yang cocok untuk berbagai lingkungan dapat dengan cepat mengidentifikasi objek dan orang, menganalisis data demografi audiens, dan memeriksa hasil produksi. Computer vision ini menggunakan pembelajaran mendalam untuk membentuk jaringan saraf yang memandu sistem dalam pemrosesan dan analisis.

Gambar atau video dapat digunakan sebagai bahan penelitian. Seperti pada gambar atau video wajah dapat diterapkan fungsi deteksi wajah sehingga dapat diketahui pemilik wajah, jenis kelamin, bahkan ekspresi pada wajah. Dalam bidang ilmu pengetahuan dan teknologi, penelitian pengenalan wajah merupakan salah satu cabang penelitian yang menghitung dan menganalisis data yang berkaitan dengan karakteristik tubuh manusia. Terdapat beberapa aspek untuk pendeteksian wajah di komputer, beberapa diantaranya yaitu kondisi ekspresi wajah, cahaya, dan aksesori yang digunakan pada wajah. Dalam proses pengenalan wajah, computer vision memiliki beberapa tahapan, antara lain pengambilan objek, pengukuran ulang objek, dan analisis pengenalan. Tahap pemotretan objek adalah tahapan dimana kamera digunakan untuk mengambil gambar suatu objek atau wajah manusia. dari gambar statis. Kemudian setelah pengambilan gambar, langkah selanjutnya adalah tahap resizing atau 
tahap re-measurement. Tahap ini merupakan tahap jembatan antara tahap pemotretan objek dan tahap analisis citra.

Pada tahap ini citra yang telah diubah ukurannya dianalisis dengan cara mencocokkan citra objek dengan koleksi citra yang ada di database untuk menentukan nilai pencocokan data, sehingga nantinya dapat diperoleh citra citra objek yang cocok. Ada beberapa cara untuk melakukan proses pengenalan wajah, salah satunya adalah penggunaan jaringan syaraf tiruan, dan salah satunya adalah deep learning. Teknologi deep learning merupakan teknologi yang populer digunakan untuk mengenali objek dengan akurasi yang lebih tinggi dibandingkan dengan metode machine learning [1], [2]. Kemampuan deep learning yang dapat melakukan pengenalan wajah memungkinkan teknologi ini dapat digunakan di segala aspek.

Pada penelitian ini akan digunakan titik-titik landmark untuk proses ekstraksi fitur sehingga perhitungan jarak untuk setiap fitur lebih akurat. Fitur geometris ini dipilih karena tidak mudah terpengaruh oleh cahaya dan gerak. Ciri geometris yang digunakan antara lain lebar hidung, tebal alis, jarak antara alis dan mata, lebar pangkal hidung, tinggi bibir atas dan tinggi bibir bawah. Saat ini, pendeteksian wajah manusia dapat dengan mudah dilakukan melalui sistem pencitraan. Citra yang diperoleh merupakan citra digital dengan menggunakan teknologi kamera digital. Salah satu kendala pada citra yang dihasilkan kamera digital adalah pencahayaan, sehingga penulis mempelajari proses deteksi dan klasifikasi wajah berdasarkan landmark wajah, menggunakan Open CV dan Dlib untuk menangani masalah pencahayaan, dan pengolahan dengan mengubah citra RGB menjadi hitam dan gambar putih masalah pencahayaan. Bedakan antara area wajah dan non-wajah. Selain itu, sistem deteksi tepi dapat menyederhanakan proses deteksi wajah dengan memperoleh sampel wajah yang sesuai.

\section{A. OpenCV}

OpenCV (Open Source Computer Vision Library) merupakan library yang dibuat oleh Intel dan didukung oleh Willow Garage dan Itseez. OpenCV ditujukan untuk pengolahan citra dinamis secara real-time. Pada OpenCV menerapkan metode Computer Vision yang memungkinkan komputer dapat melihat objek sama seperti manusia sehingga dapat mengambil keputusan dan melakukan aksi berdasarkan objek yang dideteksi. OpenCV dapat dijalankan pada multi-platform sehingga dapat diterapkan secara luas pada gambar atau video seperti face recognition, face detection, object tracking, road tracking, dll [1], [2], [3].

\section{B. Dlib}

Dlib merupakan suatu library open source yang menyediakan environment untuk pengembangan software berbasis $\mathrm{C}++$ [4]. Dlib memiliki cara kerja menganalisis bagian wajah dengan cara mengekstrak nilai pada gambar dimana hasil ekstraksi pada wajah manusia akan menghasilkan 128 dimensional feature vektor [5], [6]. Library dlib dapat digunakan pada deteksi wajah berbasis facial landmark menggunakan algoritma HOG dan SVM Classifier [7].

\section{Histogram of Oriented Gradient (HOG)}

Histogram of Oriented Gradient (HOG) digunakan untuk mengekstrak fitur pada obyek gambar dengan cara mengkonversi citra RGB (Red, Green, dan Blue) menjadi Grayscale kemudian dihitung nilai gradien dari setiap piksel pada citra tersebut karena setiap citra memiliki karakteristik. Hal tersebut ditunjukkan pada distribusi gradien yang diperoleh dengan membagi citra ke dalam daerah kecil yang disebut cell HOG dimana pada setiap cell terdiri dari sebuah histogram dari sebuah gradien yang mewakili sebuah objek. Metode HOG cocok digunakan sebagai deskriptor untuk pencarian gambar berbasis sketsa dengan mendeteksi titik interest dan dapat membedakan visual objek pada kondisi pencahayaan yang kurang terang [8], [9],[10]. Masukan berupa gambar yang telah direkam akan dicocokkan dengan data latih yang sebelumnya telah dilakukan kemudian ditentukan gambar yang paling mirip dengan pola HOG seperti pada Gambar 1 [7].

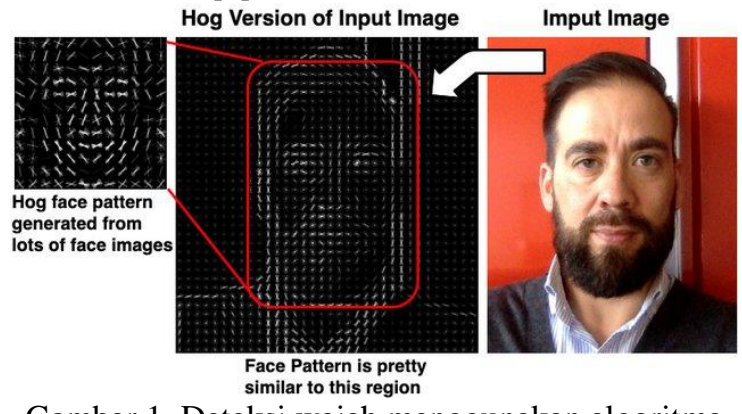

Gambar 1. Deteksi wajah menggunakan algoritma HOG

\section{Facial Landmark}

Facial landmark didefinisikan sebagai deteksi wajah berdasarkan titik-titik menonjol pada wajah yang dapat berfungsi sebagai titik jangkar pada gambar wajah [11]. Hal tersebut berfungsi untuk menentukan bentuk biologis pada wajah manusia [5]. Untuk membantu ekstraksi titik-titik pada wajah diperlukan sebuah tool atau metode seperti Dlib Regression Tree dimana metode tersebut melokalisasi 68 titik yang dilatih. Metode facial landmark dapat mendeteksi area wajah dengan mengalokasikan titiktitik pada wajah sehingga dapat dikenali oleh sistem. Metode facial landmark dapat mendeteksi bagianbagian pada wajah seperti bagian mata, alis, mulut dan hidung [5] seperti pada Gambar 2. Facial landmark dapat digunakan untuk face recognition, face reconstruction, dan analisis facial attributes seperti umur, jenis kelamin, senyum, penggunaan kacamata [12]. 


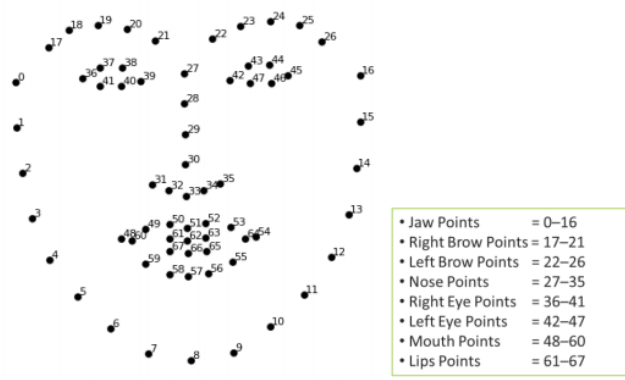

Gambar 2. Facial Landmark

\section{METODE PENELITIAN}

1. Analisis Masalah

Deteksi wajah dapat diterapkan pada berbagai kebutuhan seperti untuk pengamanan, identifikasi, teleconference, sebagai alat bantu pelacakan, dan kebutuhan lainnya. Hal ini dapat dilakukan melalui proses pencitraan image digital baik berupa gambar maupun video. Kualitas image yang dihasilkan sangat dipengaruhi oleh faktor pencahayaan. Pencahayaan yang kurang bagus dapat mengakibatkan hasil dari deteksi objek penelitian menjadi tidak sesuai atau kurang akurat dimana detektor wajah harus mengidentifikasi fitur wajah dan mengabaikan objek lain di sekitarnya [13]. Berdasarkan analisis permasalahan sehingga dapat diketahui kebutuhan sistem seperti algoritma, perangkat, antarmuka, dan teknik

2. Pengumpulan Data

Pengumpulan dataset dilakukan dengan cara melakukan pengambilan gambar terhadap objek penelitian. Pengambilan objek data yang digunakan dilakukan dengan cara mengambil gambar wajah secara keseluruhan dengan wajah menghadap ke depan. Jarak pengambilan gambar antarobjek berbeda-beda.

\section{Rancangan}

Pada tahap ini dilakukan perancangan sistem, alur, juga algoritma sistem. Pada tahap ini juga dilakukan penentuan titik pada wajah. Rancangan alur sistem deteksi wajah seperti pada Gambar 3 dimana sistem dapat mengenali wajah jika data wajah telah tersimpan, kemudian dilakukan training wajah. Selanjutnya sistem dapat melakukan pendeteksian wajah dan mencocokkan wajah terdeteksi dengan data yang telah tersimpan. Jika wajahnya memiliki kecocokan maka akan ditampilkan namanya, jika tidak sistem akan melakukan pendeteksian ulang.

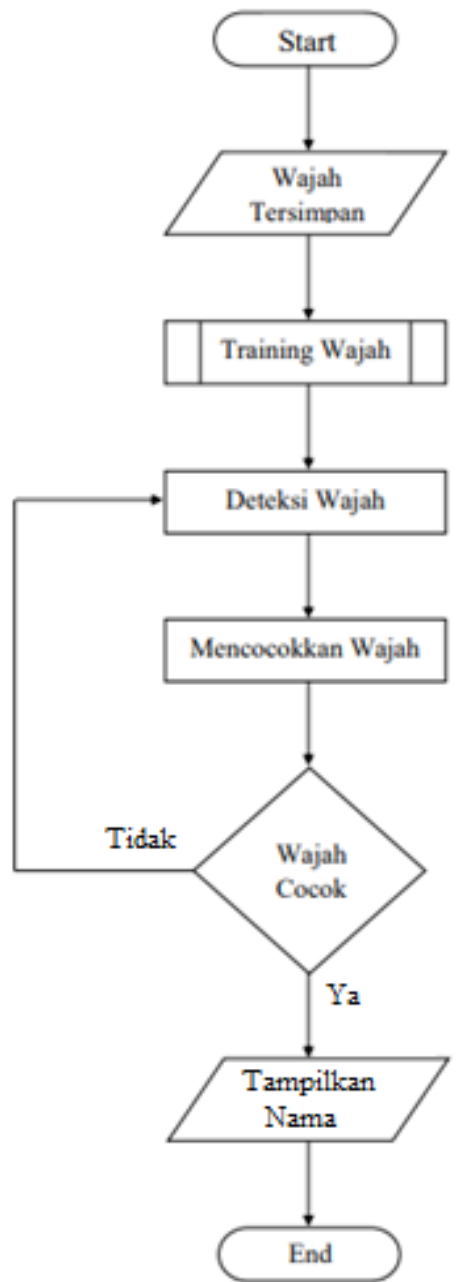

Gambar 3. Flowchart

4. Implementasi

Pada tahap implemantasi dilakukan proses pengkodean menggunakan python dan menerapkan metode deteksi wajah dengan menggunakan library OpenCV dan Dlib.

5. Pengujian

Tahap pengujian dilakukan guna mengetahui tingkat keberhasilan deteksi wajah yang telah dibangun. Pengujian dilakukan dengan menerapkan beberapa kondisi untuk mengetahui akurasi sistem.

\section{HASIL DAN PEMBAHASAN}

Metode deteksi wajah memiliki peran yang penting di dalam keberhasilannya dalam melakukan deteksi wajah untuk berbagai kebutuhan. Hasil dari rekam atau deteksi wajah dapat dilanjutkan dengan menerapkan berbagai proses seperti facial landmark, pengenalan wajah, pengenalan ekspresi wajah, dan lainnya. Keberhasilan dalam mendeteksi wajah dapat menentukan hasil analisis yang lebih akurat. 


\section{A. Facial Landmark Points}

Pengujian terhadap facial landmark dalam melakukan pendeteksian telah menunjukkan keberhasilan. Pengujian dilakukan dengan latar belakang bebas, dari pengujian ini dapat dibuktikan bahwa metode facial landmark dapat melakukan pendeteksian dengan baik di berbagai latar belakang. Sesuai dengan titik yang telah ditentukan pada facial landmark yaitu menggunakan 5 titik dan hasilnya dari kelima titik tersebut telah berhasil dialokasikan dalam pembentukan pola wajah sesuai yang ada pada gambar. Seperti yang terlihat pada Gambar 4 menunjukkan hasil dari pendeteksian dari facial landmark.

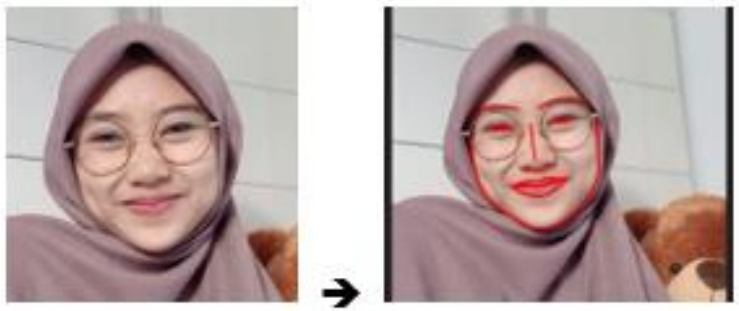

Gambar 4. Hasil Deteksi Facial Landmark

\section{B. Dlib, OpenCV, Landmark Detecton}

Pada proses ini gambar akan lebih presisi dalam menyesuaikan perputaran serta pergeseran, sehingga gambar tidak akan mudah terdistorasi. Pemrosesan gambar juga menggunakan metode transformasi gambar dasar seperti rotasi dan skala untuk mempertahankan garis paralel.

Saat dilakukan pengujian sistem, secara keseluruhan sistem dapat mendeteksi wajah dengan baik dan dapat menampilkan hasil yang sesuai. Pengujian dilakukan dengan melakukan deteksi wajah dari sisi depan dan sisi samping seperti seperti pada Gambar 5. Pada pengujian ini pengujian dilakukan menggunakan pencahayaan yang terang. Hasil pengujian berhasil mendeteksi wajah dengan sesuai.

Deteksi wajah juga dilakukan menggunakan pencahayaan yang redup. Hasil pengujian menunjukkan bahwa sistem dapat mendeteksi wajah dengan baik dan menampilkan nama yang sesuai dengan objek yang dideteksi seperti pada Gambar 6 .

Pengujian dilakukan dengan memberikan aksesoris berupa masker pada objek penelitian. Hasil pengujian menunjukkan bahwa sistem tidak mampu mendeteksi wajah dengan tepat. Hal ini terlihat dari objek yang tidak berhasil menampilkan nama maupun nama yang ditampilkan tidak sesuai dengan nama objek. Dari 4 gambar wajah pada Gambar 7 hanya ada 1 gambar yang menampilkan nama sesuai dengan objek.
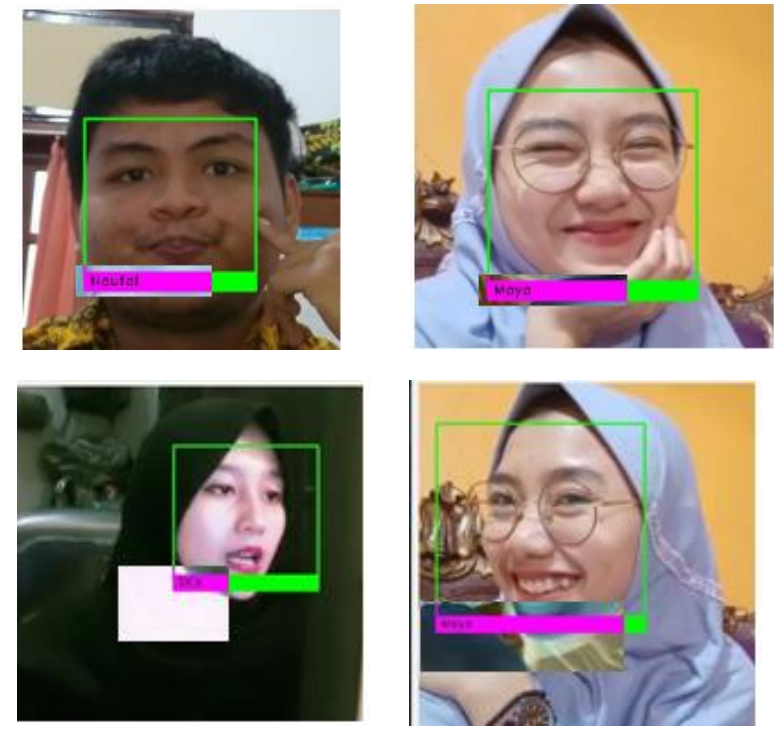

Gambar 5. Pengujian Deteksi Wajah pada Cahaya Terang
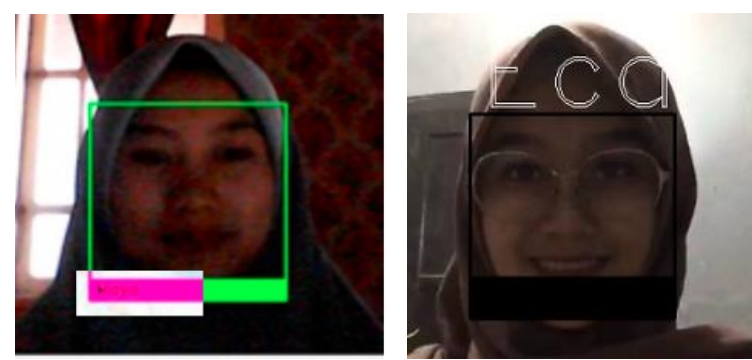

Gambar 6. Pengujian Deteksi Wajah pada Cahaya Redup
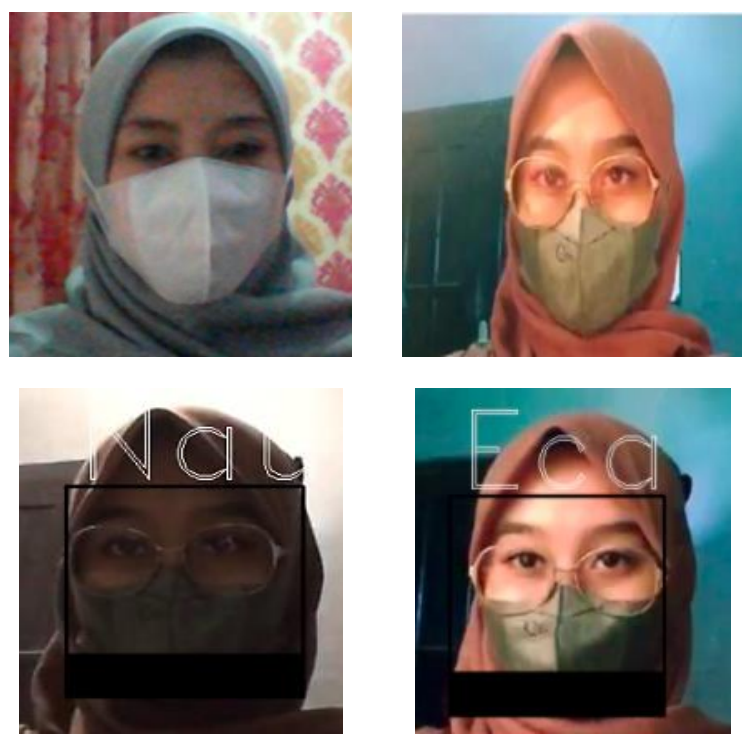

Gambar 7. Pengujian Deteksi Wajah Menggunakan Masker 


\section{KESIMPULAN}

Berdasarkan hasil dari penelitian deteksi wajah berbasis Facial Landmark menggunakan OpenCV dan Dlib dapat disimpulkan bahwa penerapan metode facial landmark dapat melakukan pendeteksian pada area wajah dengan baik menyesuaikan titik facial landmark yang telah ditentukan. Keberhasilan deteksi wajah pada sistem terjadi pada kondisi pencahayaan terang maupun redup. Namun sistem tidak bisa mendeteksi dengan baik pada saat objek menggunakan aksesoris berupa masker. Dengan menggunakan Dlib OpenCV menjadikan deteksi wajah berbasis facial landmark lebih akurat pada saat wajah tampak secara keseluruhan. Pemrosesan gambar juga menggunakan metode transformasi gambar dasar seperti rotasi dan skala. Hal tersebut dikarenakan pemrosesan pada Dlib OpenCV dapat mempresisikan gambar menyesuaikan pergerakan wajah, sehingga gambar tidak akan mudah terdistorasi.

\section{UCAPAN TERIMA KASIH}

Penelitian ini didanai oleh Kementerian Riset dan Teknologi/Badan Riset dan Inovasi Nasional (RISTEK-BRIN) 2020.

\section{DAFTAR PUSTAKA}

[1] O. Victoria and I. P. Solihin, "Pendeteksi Wajah Secara Realtime Menggunakan Metode Eigenface," Semin. Nas. Inform. Sist. Inf. Dan Keamanan Siber, pp. 126-131, 2018.

[2] T. C. A.-S. Zulkhaidi, E. Maria, and Yulianto, "Pengenalan Pola Bentuk Wajah dengan OpenCV," J. Rekayasa Teknol. Inf., vol. 3, no. 2, p. 181, 2020, doi: 10.30872/jurti.v3i2.4033.

[3] A. Sulistyowati, Y. S. Hariyani, and A. Novianti, "Perancangan Aplikasi Pembaca Warna dan Bentuk Berbasis Pengolahan Citra untuk Daftar Katalog Perpustakaan," $e$ Proceeding Appl. Sci., vol. 4, no. 3, pp. 2554 2566, 2018.

[4] S. Sharma, K. Shanmugasundaram, and S. K. Ramasamy, "FAREC - CNN based efficient face recognition technique using Dlib," Proc. 2016 Int. Conf. Adv. Commun. Control Comput. Technol. ICACCCT 2016, pp. 192195, 2016, doi: 10.1109/ICACCCT.2016.7831628.

[5] A. D. Purwanto and F. Utaminingrum, "Deteksi Pergerakan Mata dan Kedipan Untuk Memilih Empat Menu Display Menggunakan Probabilitas Berdasarkan Facial Landmark," urnal Pengemb. Teknol. Inf. dan Ilmu Komput., vol. 3, no. 11, pp. 10865-10874, 2019.

[6] R. Herawati, "Drowsinesslab: Aplikasi
Desktop Deteksi Kantuk Berbasis Facial Landmark menggunakan Open CV, Dlib, dan Tkinter," Universitas Islam Negeri Sunan Gunung Djati, 2021.

[7] L. Variz, L. Piardi, P. J. Rodrigues, and P. Leitao, "Machine Learning Applied to an Intelligent and Adaptive Robotic Inspection Station," IEEE Int. Conf. Ind. Informatics, pp. 290-295, 2019, doi: 10.1109/INDIN41052.2019.8972298.

[8] R. Y. Endra, A. Cucus, F. N. Affandi, and M. B. Syahputra, "Deteksi Objek Menggunakan Histogram of Oriented Gradient (HOG) untuk Model Smart Room," Explor. (Jurnal Sist. Inf. dan Telemat., vol. 9, no. 2, pp. 99-105, 2018.

[9] A. F. Randa, N. Suciati, and D. A. Navastara, "Implementasi Metode Kombinasi Histogram of Oriented Gradients dan Hierarchical Centroid untuk Sketch Based Image Retrieval," J. Tek. ITS, vol. 5, no. 2, pp. 311316, 2016, doi: 10.12962/j23373539.v5i2.16984.

[10] M. Fauziah, "Perancangan dan Implementasi Sistem Deteksi Pergerakan Kepala, Mata, dan Alis Berbasis Machine Learning," Institut Teknologi Bandung, 2021.

[11] Ulla Delfana Rosiani, Rosa Andrie Asmara, and Nadhifatul Laeily, "Penerapan Facial Landmark Point Untuk Klasifikasi Jenis Kelamin Berdasarkan Citra Wajah," J. Inform. Polinema, vol. 6, no. 1, pp. 55-60, 2020, doi: 10.33795/jip.v6i1.328.

[12] X. Tang, F. Guo, J. Shen, and T. Du, "Facial Landmark Detection by Semi-Supervised Deep Learning," Neurocomputing, vol. 297, no. February 2018, pp. 22-32, 2018, doi: 10.1016/j.neucom.2018.01.080.

[13] R. A. A. Manullang, "Identifikasi Wajah Menggunakan Metode Eigenfaces dan Euclidean Distance," Univeristas Sriwijaya, 2019. 